\title{
Pengaruh Likuiditas, Ukuran Perusahaan, Profitabilitas dan Laverage Terhadap Nilai Perusahaan pada Perusahaan Sub Sektor Wholesale Yang Terdaftar di Bursa Efek Indonesia Periode 2014-2018
}

\author{
Andreas Siagian*, Desstevinalia Br Surbakti \\ Program Studi S1-Manajemen, Fakultas Ekonomi Universitas Prima Indonesia \\ *Correspondence email: andreassiagian72@gmail.com, despisurbakti@gmail.com
}

\begin{abstract}
Abstrak. Penelitian ini bertujuan menjelaskan pengaruh variabel likuiditas, ukuran perusahaan, profitabilitas dan leverage terhadap nilai perusahaan pada sub sektor wholesale yang terdaftar di Bursa Efek Indonesia pada periode 2014-2018. Populasi penelitian ini adalah 45 perusahaan sub sektor wholesale dan hanya 13 perusahaan yang memnenuhi kriteria dengan teknik purposive sampling. Penelitian ini menggunakan data sekunder dengan uji asumsi klasik dan analisis regresi berganda. Hasil penelitian menunjukkan bahwa likuiditas, profitabilitas dan leverage secara parsial memiliki pengaruh dan signifikan terhadap nilai perusahaan, sedangan ukuran perusahaan secara parsial tidak memiliki pengaruh dan tidak signifikan terhadap nilai perusahaan. secara simultan likuiditas, ukuran perusahaan, profitabilitas dan leverage berpengaruh dan signifikan terhadap nilai perusahaan pada sub sektor wholesale yang terdaftar di Bursa Efek Indonesia pada periode 2014-2018. Berdasarkan uji koefisien determinasi diperoleh nilai R Square sebesar 0,372 dengan tingkat 37,2 persen. Jadi, pengaruh likuiditas, ukuran perusahaan, profitabilitas dan leverage terhadap nilai perusahaan sebesar 37,2 dan sisanya 62,8 di pengaruh oleh variabel lain yang tidak diteliti dapa penelitian ini.
\end{abstract}

Kata Kunci: likuiditas; ukuran perusahaan profitabilitas; leverage dan nilai perusahaan

\begin{abstract}
This study aims to explain the influence of variable liquidity, company size, profitability and leverage on the value of companies in the wholesale sub-sector listed on the Indonesia Stock Exchange in the period 2014-2018. The population of this study was 45 wholesale sub-sector companies and only 13 companies met the criteria with purposive sampling techniques. The study used secondary data with classical assumption tests and multiple regression analyses. The results showed that liquidity, profitability and leverage partially have an influence and significant on the value of the company, while the size of the company partially has no influence and is insignificant to the value of the company. Simultaneously liquidity, company size, profitability and leverage influenced and significant impact on the value of the company in the wholesale sub-sector listed on the Indonesia Stock Exchange in the period 2014-2018. Based on the coefficient of determination test obtained the value of $R$ Square of 0.372 with a rate of 37.2 percent. Thus, the influence of liquidity, company size, profitability and leverage on the company's value was 37.2 and the remaining 62.8 was influenced by other variables not studied in this study.
\end{abstract}

Keywords: liquidity; size of the company's profitability; leverage and value of the company

\section{Pendahuluan}

Dalam dunia bisnis Nilai Perusahaan merupakan faktor yang krusial bagi investor, dimana jika nilai suatu perusahaan tinggi itu berrarti tingkat pengembalian atas saham juga naik yang akan memberikan ketenangan bagi investor yang telah menanamkan modalnya. Karena jika lemahnya nilai perusahaan otomatis pembagian dividen terhadap investor juga akan menurun bahkan akan memberikan kerugian baik para pemegang saham atau pemilik perusahaan. Suatu perusahaan yang telah terbuka atau telah menawarkan saham ke publik maka nilai perusahaan diartikan sebagai persepsi seorang investor terhadap perusahaan itu sendiri. Investor dapat mempergunakan nilai perusahaan sebagai dasar untuk melihat kinerja perusahaan pada periode mendatang, dimana nilai perusahaan sering dikaitkan dengan harga saham. Investor akan memperoleh keuntungan apabila harga saham perusahaan tinggi. Ada beberapa faktor yang mempengaruhi Nilai perusahaan salah satunya Rasio Likuiditas. Likuiditas menggambarkarn kemampuan perusahaan untuk memenuhi kewajiban keuangan jangka pendeknya yang segera harus dipenuhi pada saat ditagih untuk mempertahankan likuiditasnya.

Rasio likuiditas adalah kemampuan perusahaan untuk memenuhi atau membayar kewajiban jangka pendeknya secara tepat waktu. perusahaan yang mempunyai tingkat likuiditas yang tinggi mengindikasikan kesempatan bertumbuh perusahaan cenderung tinggi. Semakin likuid perusahaan, maka semakin tinggi tingkat kepercayaan kreditur dalam memberikan dananya, sehingga dapat meningkatkan nilai perusahaan di mata kreditur maupun pada calon investor. Ukuran perusahaan dianggap mampu mempengaruhi nilai perusahaan karena semakin besar ukuran atau skala perusahaan maka akan semakin mudah pula perusahaan memperoleh sumber pendanaan baik yang bersifat internal maupun eksternal. Yang manadana yang bersifat internal yaitu dari Aset yang dimiliki perusahaan sedangkan dana dari luar perusahaan berasal dari investor. Semakin tinggi ukuran perusahaan akan membuat nilai perusahaan meningkat. Profitabilitas juga dapat memengaruhi nilai perusahaan. Besar kecilnya profitabilitas yang dihasilkan suatu 
perusahaan dapat memengaruhi nilai perusahaan dengan melihat profitabilitas sebagai ukuran dan kinerja perusahaan yang ditunjukan dari laba yang dihasilkan oleh perusahaan.Tanpa adanya keuntungan akan sulit bagi perusahaan untuk menarik modal dari luar. Perusahaan yang memiliki tingkat profitabilitas yang tinggi akan diminati sahamnya oleh investor. Adapun laba yang dihasilkan perusahaan berasal dari penjualan produk dan investasi yang dilakukan oleh perusahaan. Laba yang dihasilkan perusahaan berasal dari penjualan produk dan investasi yang dilakukan oleh perusahaan. Perusahaan yang memiliki profitabilitas yang tinggi menunjukan bahwa perusahaan tersebut mengelola kekayaan perusahaan secara efektif dan efisien dalam memperoleh laba setiap periode. Hal ini akan membuat nilai perusahaan tersetur ikut mengalami kenaikan.

Peningkatan leverage bisa memberi dua macam signal, yaitu berita baik ( good news) sekaligus berita buruk (bad news). Peningkatan leverage menunjukkan berita baik (good news) jika peningkatan tersebut merefleksi kemampuan manajemen untuk meningkatkan nilai perusahaan. Rasio hutang dalam penelitian ini diproksi menjadi Debt to Equity Ratio (DER) yang merupakan perbandingan jumlah pinjaman jangka panjang yang dimiliki perusahaan dengan jumlah modal sendiri. Dengan adanya hutang, maka dapat digunakan untuk mengendalikan aliran kas secara berlebihan oleh manajemen, dengan demikian menghindari investasi yang sia-sia dan akan meningkatkan nilai perusahaan. Perusahaan wholesale merupakan salah satu jenis perusahaan yang terdaftar di Bursa Efek Indonesia. Wholesale atau distributor melakukan kegiatan pembelian, penjualan, pengiriman, hingga pembayaran kepada produsen. Dalam penelitian ini, perusahaan di sektor industri wholesale dan retail trade digunakan sebagai objek penelitian karena perkembangan bisnis wholesale dan ritel di Indonesia yang berkembang pesat dan semakin banyaknya perusahaan ritel asing yang mulai memasuki pasar di Indonesia. Walaupun demikian Nilai Perusahaan pad sub sektor Wholwsale tidak selama mengalami peningkatan seperti pada tahun 2014-2015 Nilai perusahaan padasub sektor Wholesale meningkat sebanyak 0,198 atau 19,8\% dimana total Nilai Perusahan pada tahun 2014 sebesar 5,0245332 yang naik menjadi 6,019061 pada tahun 2015. Untuk tahun 2015 ke tahun 2016 nilai perusahaan mengalami penurun sebesar 0,301 atau 30,1\% dimana total nilai perusahaan pada tahun 2015 sebesar 6,019061 turun menjadi 4,208148 pada tahun 2016. Hal serupa juga terjadi pada 2017 sampai 2018 yang mana nilai perusahaan mengalami penurunan sebesar 0,221 atau 22,1\% diman total nilai perusahaan pada tahun 2017 sebesar 3,920217 turun menjadi 3,055094. Kenaikan atau penurunan yang dialami oleh perusahaan sub sektor Wholesale bisa disebab oleh ketidakstabilan ekonomi atau harga yang ditawarkan oleh produsen, sebab perusahaan distributor keuntunganya mengandalkan dari selisih beli dari produsen barang.

Tujuan penelitian ini adalah untuk mengetahui pengaruh likuiditas, ukuran perusahaan, profitabilitas dan leverage terhadap nilai perusahaan pada perusahaan sub sektor wholesale yang terdaftar di Bursa Efek Indonesia periode 2014-2018.

\section{Nilai Perusahaan}

Menurut (Sartono, 2010) nilai perusahaan adalah nilai jual sebuah perusahaan sebagai suatu bisnis yang sedang beroperasi. Adanya kelebihan nilai jual diatas nilai likuidasi adalah nilai dari organisasi manajemen yang menjalankan perusahaan itu. Sedangkan menurut Harmono (2014) nilai Perusahaan adalah kinerja perusahaan yang dicerminkan oleh harga saham yang dibentuk oleh permintaan dan penawaran pasar modal yang merefleksikan penilaian masyarakat terhadap kinerja perusahaan. Nilai perusahaan dalam penelitian ini diukur dengan Price to Book Value (PBV) ratio. Rasio ini untuk mengetahui seberapa besar harga saham yang ada di pasar dibandingkan dengan nilai buku sahamnya. Semakin tinggi rasio ini maka tinggi pula nilai perusahaan.

\section{Likuiditas}

Menurut Kasmir (2016), rasio likuiditas adalah rasio yang menunjukkan kemampuan perusahaan dalam membayar utang-utang jangka pendeknnya yang jatuh tempo atau rasio untuk mengetahui kemampuan perusahaan dalam membiayai dan memenuhi kewajiban pada saat ditagih. Ada beberapa jenis rasio Likuiditas yaitu current ratio, quick ratio, cash ratio dan cash turnover ratio. Penelitian ini peneliti memakai current ratio. Current ratio ini bertujuan untuk mengetahui sebanyak apa aset lancar yang dimiliki oleh perusahaan jika dibandingkan dengan utang lancarnya. Teori yang dikemukakan Fahmi (2014) yaitu dalam rangka memperkecil risiko likuiditas maka perusahaan harus memperkuat nilai likuiditas. Karena perusahaan yang memiliki rasio likuiditas tinggi akan diminati para investor dan akan berimbas pula pada harga saham yang cenderung akan naik karena tingginya permintaan dimana harga saham mencerminkan nilai perusahaan.

\section{Ukuran Perusahaan}

Rianto (2012) mengatakan bahwa ukuran perusahaan (firm size) menggambarkan besar kecilnya suatu perusahaan yang ditujukan pada total aktiva, jumlah penjualan, dan rata-rata penjualan. Pada penelitian ini menggunakan log total asset. Dengan menggunakan log natural, jumlah asset dengan nilai ratusan miliar bahkan 
triliun akan disederhanakan, tanpa mengubah proporsi dari jumlah asset yang sesungguhnya. Ukuran perusahaan yang besar menunjukkan perusahaan mengalami perkembangan sehingga investor akan merespon positif dan nilai perusahaan akan meningkat. (Riyanto, 2011) berpendapat bahwa perusahaan yang besar dengan sebaran saham perusahaan yang besar pula akan memiliki dampak yang kecil terhadap hilangnya kontrol dari pihak dominan terhadap perusahaan, jadi perusahaan yang berukuran besar cenderung lebih berani untuk mengeluarkan saham baru guna memenuhi kebutuhan perusahaan ketimbang perusahaan kecil.

\section{Profitabilitas}

Menurut (Sartono, 2012), profitabilitas merupakan rasio yang mengukur kemampuan perusahan untuk menghasilkan laba baik dalam hubungannya dengan penjualan, asetmaupun laba bagi modal sendiri.Dengan demikian bagi investor jangka panjang akan sangat bekepentingan dengan analisis profitabilitas ini misalnya bagi pemegang saham akan melihat keuntungan yang benar-benar akan diterima dalam bentuk dividen.

\section{Leverage}

Rasio Leverage ratio merupakan rasio yang digunakan untuk mengukur sejauh mana aktiva perusahaan dibiayai dengan utang. Artinya berapa besar beban utang yang ditanggung perusahaan dibandingkan dengan aktivanya. Dalam arti luas dikatakan bahwa leverage digunakan untuk mengukur kemampuan perusahaan untuk membayar seluruh kewajibannya, baik jangka pendek maupun jangka panjang apabila perusahaan dibubarkan (Kasmir, 2016). Keputusan pendanaan yang dilakukan perusahaan untuk menggunakan utang (leverage) dalam membiayai investasi diharapkan dapat meningkatkan nilai perusahaan, sehingga dapat memberikan kemak-muran pemegang sahamnya, karena penggunaan hutang memiliki dua keunggulan penting. Pertama,bunga dibayarkan dapat menjadi pengurang pajak,yang selanjutnya akan menurunkan biaya efektif utangtersebut. Kedua, kreditor akan mendapatkan pengem-balian dalam jumlah tetap, sehingga pemegang saham tidak harus membagi keuntungannya jika bisnis berjalan sangat baik, (Brigham \& Houston, 2011).

\section{Metode}

Populasi dalam penelitian ini adalah perusahaan sub sektor Wholesale yang terdaftar di Bursa Efek Indonesia periode 2014-2018. Jumlah populasi dalam penelitian ini sebanyak 45 perusahaan. Sampel adalah bagian dari jumlah dan karakteristik yang dimiliki oleh populasi tersebut. Purposive sampling adalah sebagai berikut:"Sampling purposive adalah teknik penentuan sampel dengan pertimbangan tertentu". Alasan penelitin memilih teknik purposive sampling dikarenakan karena tidak semua sampel memiliki kriteria sesuai dengan yang telah penulis tentukan. Oleh karena itu, sampel yang dipilih sengaja ditentukan berdasarkan kriteria tertentu yang telah ditentukan.

Tabel 1

Kriteria Sampel Penelitian

\begin{tabular}{|c|l|r|}
\hline No & \multicolumn{1}{|c|}{ Kriteria } & \multicolumn{1}{|c|}{ Jumlah Sampel } \\
\hline 1 & $\begin{array}{l}\text { Perusahaan sub sektor Wholesale yang terdaftar di Bursa Efek Indonesia pada periode 2014- } \\
2018 .\end{array}$ & 45 \\
\hline 2 & $\begin{array}{l}\text { Perusahaan sub sektor Wholesale yang terdaftar di Bursa Efek Indonesia yang tidak } \\
\text { mempublikasikan laporan keuangan dengan lengkap dan berturut-turut selama periode 2014- } \\
2018 .\end{array}$ & $(14)$ \\
\hline 3 & $\begin{array}{l}\text { Perusahaan sub sektor Wholesale yang terdaftar di Bursa Efek Indonesia yang tidak } \\
\text { mempublikasikan harga saham dengan lengkap dan berturut-turut selama periode 2014-2018. }\end{array}$ & $(2)$ \\
\hline 4 & $\begin{array}{l}\text { Perusahaan sub sektor Wholesale yang terdaftar di Bursa Efek Indonesia yang memiliki laba } \\
\text { negatif selama periode 2014-2018. }\end{array}$ & $\begin{array}{r}13 \\
\text { Total perusahaan yang memenuhi kriteria sampel } \\
\text { Tahun pengamatan } \\
\text { Total sampel selama periode berjalan (13 x 5) }\end{array}$ \\
\hline
\end{tabular}

Sumber : Bursa Efek Indonesia

\section{Metode Teknik Analisis Data}

Analisis atau pengujian terhadap data dilakukan melalui beberapa tahap. Statistik deskriptif digunakan untuk memberikan deskripsi tentang data setiap variabel-variabel yang digunakan didalam penelitian. Tahap awal yaitu uji asumsi klasik yang terdiri dari uji normalitas, Uji Multikolinearitas, Uji Autokorelasi dan Uji Heteroskesdastisitas tahap kedua adalah analisis data terdiri dari analisis linier berganda dan analisis koefisien determinasi. Persamaan regresi berganda bertujuan untuk mengukur kekuatan asosiasi linear antara dua variabel. (Ghozali: 2018) Persamaan model regresi berganda adalah: 
Andreas Siagian dan Desstevinalia Br Surbakti, Pengaruh Likuiditas, Ukuran Perusahaan, Profitabilitas dan Laverage Terhadap Nilai Perusahaan pada Perusahaan Sub Sektor Wholesale yang Terdaftar di Bursa Efek Indonesia Periode 2014-2018

Keterangan: $\mathrm{Y}=$ Harga Saham; $\mathrm{a}=$ Konstanta; $\mathrm{b}=$ Koefisien; Regresi Variabel X1, X2, X3; X1 = Profitabilitas; X2 $=$ Risiko Keuangan; $\mathrm{X} 3=$ Pertumbuhan Perusahaan; $\mathrm{e}=$ eror

Tahap terakhir adalah melakukan pengujian terhadap hipotesis (uji signifikan dari regresi sample (uji F) dan uji parameter individual (T)) yang telah dirumuskan dan diajukan.

\section{Hasil}

Tabel 2

Hasil Uji Descriptive Statistics

\begin{tabular}{|l|r|r|r|r|r|}
\hline & N & \multicolumn{1}{|c|}{ Minimum } & \multicolumn{1}{c|}{ Maximum } & \multicolumn{1}{c|}{ Mean } & \multicolumn{1}{c|}{ Std. Deviation } \\
\hline Ln_Likuiditas & 65 &,- 0497 & 3,7458 &, 651343 &, 6752222 \\
\hline Ln_Ukuran Perusahaan & 65 & 2,7208 & 3,3928 & 3,098440 &, 2413366 \\
\hline Ln_Profitabilitas & 65 & $-5,0656$ & $-1,1714$ & $-2,989662$ &, 6454282 \\
\hline Ln_Leverage & 65 & $-1,3877$ & 1,4205 &,- 010640 &, 7713700 \\
\hline Ln_Nilai Perusahaan & 65 & $-1,2108$ & 1,9948 &, 104518 &, 7845498 \\
\hline Valid N (Listwise) & 65 & & & & \\
\hline
\end{tabular}

Sumber : olahan data

Berdasarkan tabel di atas setelah di transformasi dapat dilihat bahwa nilai minimum dan nilai maksimum, nilai rata-rata (Mean) dan standar deviasi dari Likuiditas $\left(\mathrm{X}_{1}\right)$, Ukuran Perusahaan $\left(\mathrm{X}_{2}\right)$, Profitabilitas $\left(\mathrm{X}_{3}\right)$, Leverage $\left(\mathrm{X}_{4}\right)$ dan Nilai Perusahaan (Y) sebagai berikut:

1. Likuiditas $\left(\mathrm{X}_{1}\right)$, dengan sampel sebanyak 65 memiliki nilai minimum -0-,0497 dan nilai maksimum sebesar 3,7458. Sedangkan untuk nilai rata-rata (Mean) 0,651343 dan untuk standar deviasi sebesar 0,6752222.

2. Ukuran Perusahaan (X2), dengan sampel sebanyak 65 memiliki nilai minimum 2,7208 dan nilai maksimum sebesar 3,3928. Sedangkan untuk nilai rata-rata (Mean) 3,098440 dan untuk standar deviasi sebesar 0,2413366.

3. Profitabilitas $\left(\mathrm{X}_{3}\right)$ dengan sampel sebanyak 65 memiliki nilai minimum $-5,0656$ dan nilai maksimum sebesar 1,1714. Sedangkan untuk nilai rata-rata (Mean) -2,989662 dan untuk standar deviasi sebesar 0,6454282.

4. Leverage $\left(\mathrm{X}_{4}\right)$ dengan sampel sebanyak 65 memiliki nilai minimum -1,3877 dan nilai maksimum sebesar 1,4205. Sedangkan untuk nilai rata-rata (Mean) -0,010640 dan untuk standar deviasi sebesar 0,7713700.

5. Nilai Perusahaan (Y) dengan sampel sebanyak 65 memiliki nilai minimum -1,2108 dan nilai maksimum sebesar 1,9948. Sedangkan untuk nilai rata-rata (Mean) 0,104518 dan untuk standar deviasi sebesar 0,7845498.

Uji normalitas dengan grafik histogram menunjukkan distribusi data mengikuti kurva berbentuk lonceng, maka dapat disimpulkan bahwa model regresi telah memenuhi asumsi normalitas, maka dapat disimpulkan bahwa model regresi telah memenuhi asumsi normalitas.

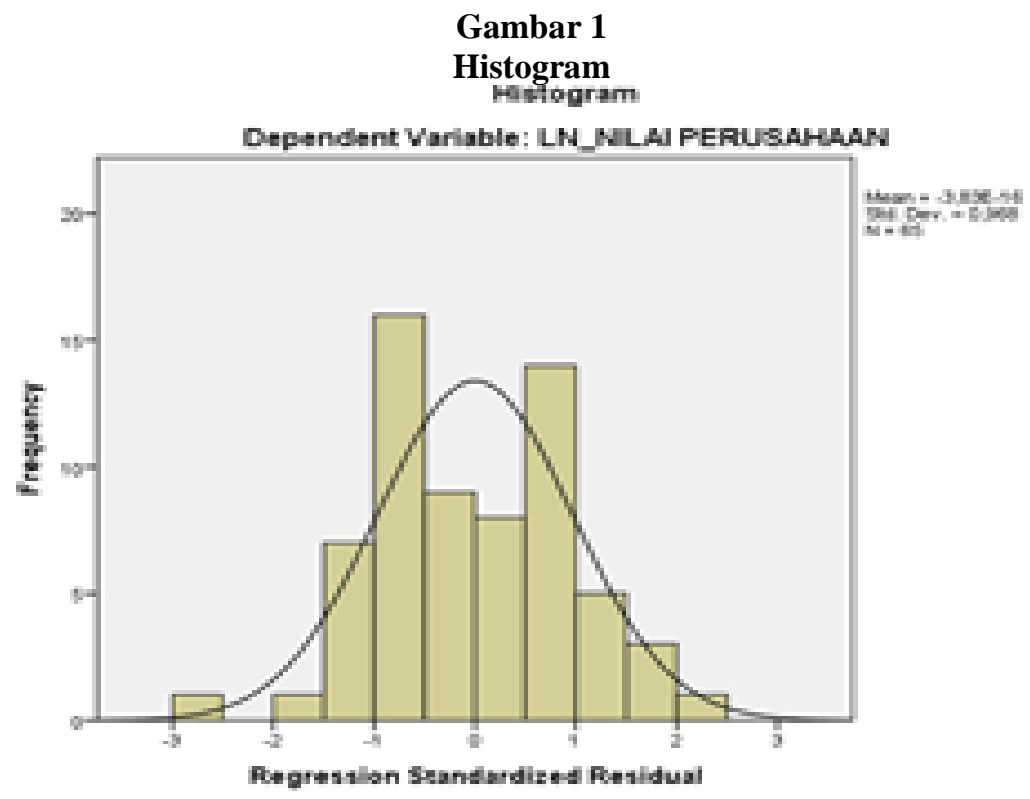

Sumber : olahan data 
Andreas Siagian dan Desstevinalia Br Surbakti, Pengaruh Likuiditas, Ukuran Perusahaan, Profitabilitas dan Laverage Terhadap Nilai Perusahaan pada Perusahaan Sub Sektor Wholesale yang Terdaftar di Bursa Efek Indonesia Periode 2014-2018

Tabel 3

Hasil Uji One-Sample Kolmogorov-Smirnov Test

\begin{tabular}{|l|l|r|}
\hline \multicolumn{2}{|l|}{} & \multicolumn{2}{|c|}{ Unstandardized Residual } \\
\hline $\mathrm{N}$ & Mean & 65 \\
\cline { 2 - 3 } Normal Parameters & Std. Deviation &, 62157486 \\
\hline \multirow{3}{*}{ Most Extreme Differences } & Absolute &, 083 \\
\cline { 2 - 3 } & Positive &, 083 \\
\cline { 2 - 3 } & Negative &,- 078 \\
\hline Kolmogorov-Smirnov Z &, 665 \\
\hline Asymp. Sig. (2-tailed) &, 768 \\
\hline
\end{tabular}

Sumber : olahan data

Dapat dilihat bahwa nilai Asymp. Sig. (2-tailed) pada data sesudah ditranformasi sebesar 0,814. Dimana nilai Asymp. Sig. (2-tailed) > nilai signifikan 0,05 sehingga data tersebut disimpulkan berdistribusi normal.

Tabel 4

Hasil Uji Multikolinearitas

\begin{tabular}{|c|c|c|c|c|c|c|c|c|}
\hline \multirow{2}{*}{\multicolumn{2}{|c|}{ Model }} & \multicolumn{2}{|c|}{ Unstandardized Coefficients } & \multirow{2}{*}{$\begin{array}{c}\text { Standardized Coefficients } \\
\text { Beta } \\
\end{array}$} & \multirow[t]{2}{*}{$t$} & \multirow[t]{2}{*}{ Sig. } & \multicolumn{2}{|c|}{ Collinearity Statistics } \\
\hline & & $\mathrm{B}$ & Std. Error & & & & Tolerance & VIF \\
\hline \multirow{5}{*}{1} & (Constant) & 1,378 & 1,199 & & 1,150 &, 255 & & \\
\hline & Ln_Likuiditas & 691 &, 165 &, 595 & 4,197 &, 000 & 521 & 1,921 \\
\hline & Ln_Ukuran Perusahaan & 207 & 342 &, 064 &, 605 &, 548 & 947 & 1,056 \\
\hline & Ln_Profitabilitas & ,788 &, 153 & 649 & 5,170 &, 000 &, 664 & 1,505 \\
\hline & Ln_Leverage &, 592 &, 163 &, 582 & 3,629 &, 001 & 406 & 2,461 \\
\hline
\end{tabular}

Sumber : olahan data

Hasil di atas setelah ditransformasi dapat diketahui nilai variance inflation factor (VIF) variabel Likuiditas, Ukuran Perusahaan, Profitabilitas dan Leverage $<10$ dan nilai Tolerance $>0,1$ sehingga bisa disimpulkan bahwa antar variabel independen tidak terjadi persoalan multikolinearitas.

Tabel 5

Hasil Uji Autokorelasi

\begin{tabular}{|l|l|r|r|r|r|}
\hline Model & R & \multicolumn{1}{c|}{ R Square } & Adjusted R Square & Std. Error of the Estimate & Durbin-Watson \\
\hline 1 &, $610^{\mathrm{a}}$ &, 372 &, 330 &, 6419598 & 1,710 \\
\hline
\end{tabular}

Sumber : olahan data

Hasil output di atas setelah ditransformasi didapat nilai Durbin-Watson yang dihasilkan dari model regresi adalah 1,710. Nilai $\mathrm{du}=1,7311 \mathrm{dl}=1,4709$ nilai DW terletak diantara nilai du dan dl. sehingga tidak ada kesimpulan yang pasti apakah ada atau tidaknya gejala autokorelasi dari data tersebut. Sehingga di perlukan uji run test. Dasar pengambilan keputusan dalam uji run test, yaitu :

- Jika nilai Asymp. Sig. (2-tailed) lebih kecil < 0,05 maka terdapat gejala autokorelasi

- Sebaliknya jika nilai Asymp. Sig. (2-tailed) lebih besar > 0,05 maka tidak terdapat gejala autokorelasi

Tabel 6

Hasil Uji Runs Test

\begin{tabular}{|l|r|}
\hline & Unstandardized Residual \\
\hline Test Value ${ }^{\mathrm{a}}$ &,- 01831 \\
\hline Cases $<$ Test Value & 32 \\
\hline Cases >= Test Value & 33 \\
\hline Total Cases & 65 \\
\hline Number of Runs & 36 \\
\hline Z &, 627 \\
\hline Asymp. Sig. (2-tailed) &, 531 \\
\hline
\end{tabular}

Sumber : olahan data 
Andreas Siagian dan Desstevinalia Br Surbakti, Pengaruh Likuiditas, Ukuran Perusahaan, Profitabilitas dan Laverage Terhadap Nilai Perusahaan pada Perusahaan Sub Sektor Wholesale yang Terdaftar di Bursa Efek Indonesia Periode 2014-2018

Berdasarkan tabel diatas diketahui nilai Asymp. Sig. (2-tailed) lebih besar 0,531 >0,05 maka tidak terdapat gejala autokorelasi. Dengan demikian, masalah uji autokorelasi yang tidak dapat diselesaikan dengan durbin watson dapat teratasi dengan uji run test.

Gambar 3

Hasil Uji Heteroskedastisitas Scatterplot

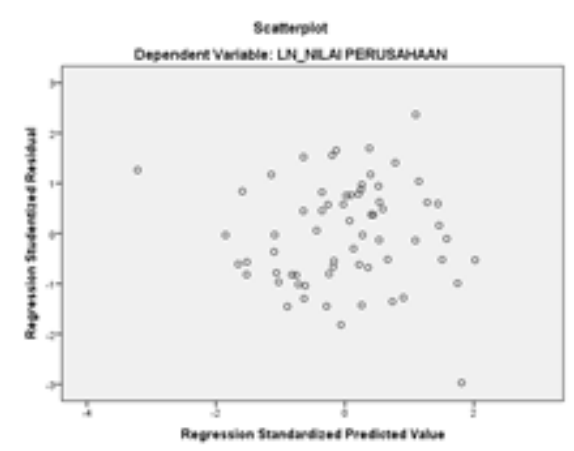

Sumber : olahan data

Hasil diatas setelah data ditransformasi menunjukkan bahwa data tersebut menyebar secara acak dan tidak membentuk suatu pola yang baik. Data tersebar dan dibawah garis 0 pada sumbu Y yang menunjukkan tidak terjadi heteroskedastisitas.

Tabel 7

Hasil Uji Gletser

\begin{tabular}{|c|c|c|c|c|c|c|}
\hline \multirow{2}{*}{\multicolumn{2}{|c|}{ Model }} & \multicolumn{2}{|c|}{ Unstandardized Coefficients } & \multirow{2}{*}{$\begin{array}{c}\text { Standardized Coefficients } \\
\text { Beta }\end{array}$} & \multirow[t]{2}{*}{$\mathrm{t}$} & \multirow[t]{2}{*}{ Sig. } \\
\hline & & B & Std. Error & & & \\
\hline \multirow{5}{*}{1} & (Constant) &, 070 &, 634 & &, 110 &, 913 \\
\hline & Ln_Likuiditas &, 016 &, 087 &, 032 &, 183 &, 856 \\
\hline & Ln_Ukuran Perusahaan &, 140 &, 181 &, 100 &, 777 &, 440 \\
\hline & Ln_Profitabilitas &, 000 &, 081 &,- 001 &,- 003 &, 997 \\
\hline & Ln Leverage &,- 089 &, 086 &,- 202 & $-1,029$ &, 308 \\
\hline
\end{tabular}

Sumber : olahan data

Output di atas sesudah ditranformasi dapat diketahui bahwa nilai signifikansi ketiga variabel independen Likuiditas, Ukuran Perusahaan, Profitabilitas dan Leverage $>0,05$ Maka dapat disimpulkan bahwa tidak terjadi heteroskedastisitas antara variabel independen dalam model regresi.

Tabel 8

Hasil Uji Analisis Regresi Linear Berganda

\begin{tabular}{|c|c|c|c|c|c|c|}
\hline \multirow{2}{*}{\multicolumn{2}{|c|}{ Model }} & \multicolumn{2}{|c|}{ Unstandardized Coefficients } & \multirow{2}{*}{$\frac{\text { Standardized Coefficients }}{\text { Beta }}$} & \multirow[t]{2}{*}{$t$} & \multirow{2}{*}{ Sig. } \\
\hline & & B & Std. Error & & & \\
\hline \multirow{5}{*}{1} & (Constant) & 1,378 & 1,199 & & 1,150 & 255 \\
\hline & Ln Likuiditas &, 691 &, 165 &, 595 & 4,197 &, 000 \\
\hline & Ln Ukuran Perusahaan & 207 & 342 &, 064 &, 605 &, 548 \\
\hline & In Profitabilitas & 788 & .153 & 649 & 5,170 & .000 \\
\hline & Ln_Leverage &, 592 &, 163 &, 582 & 3,629 &, 001 \\
\hline
\end{tabular}

Sumber : olahan data

Berdasarkan hasil diatas maka persamaan regresi linier berganda hipotesis penelitan yaitu sebagai berikut: $\mathrm{LN} \_$Nilai Perusahaan $=1,378+0,691 \mathrm{X}_{1}+0,207 \mathrm{X}_{2}+0,788 \mathrm{X}_{3}+0,592 \mathrm{X}_{4}$

Persamaan linier berganda hipotesis penelitian tersebut maka diperoleh keterangan sebagai berikut :

1. Nilai konstanta (a) adalah 1,378 artinya jika variabel bebas Likuiditas $\left(\mathrm{X}_{1}\right)$, Ukuran Perusahaan $\left(\mathrm{X}_{2}\right)$, Profitabilitas $\left(\mathrm{X}_{3}\right)$, Leverage $\left(\mathrm{X}_{4}\right)$ dianggap konstan, maka nilai Perusahaan pada perusahaan sub sektor Wholesale yang terdaftar di Bursa Efek Indonesia sebesar 137,8 persen.

2. Nilai koefisien regresi Likuiditas adalah 0,691. Ini menunjukkan bahwa setiap kenaikan Likuiditas satu persen maka akan dilihat kenaikan Nilai Perusahaan sebesar 69,1 persen. 
Andreas Siagian dan Desstevinalia Br Surbakti, Pengaruh Likuiditas, Ukuran Perusahaan, Profitabilitas dan Laverage Terhadap Nilai Perusahaan pada Perusahaan Sub Sektor Wholesale yang Terdaftar di Bursa Efek Indonesia Periode 2014-2018

3. Koefisien regresi Ukuran Perusahaan adalah 0,207. Ini menunjukkan bahwa setiap kenaikan Ukuran Perusahaan satu persen maka akan dilihat kenaikan Nilai Perusahaan 20,7 persen.

4. Koefisien regresi Profitabilitas adalah 0,788. Ini menunjukkan bahwa setiap penurunan Profitabilitas satu persen maka akan kenaikan Nilai Perusahaan 78,8 persen.

5. Koefisien regresi Leverage adalah 0,592. Ini menunjukkan bahwa setiap kenaikan Leverage satu persen maka akan dilihat kenaikan Nilai Perusahaan 59,2 persen.

Tabel 9

Hasil Uji koefisien determinasi

\begin{tabular}{|c|r|r|r|r|}
\hline Model & R & R Square & Adjusted R Square & \multicolumn{2}{c|}{ Std. Error of the Estimate } \\
\hline 1 &, $610^{\mathrm{a}}$ &, 372 &, 330 &, 6419598 \\
\hline
\end{tabular}

Sumber : olahan data

Berdasarkan tabel diatas setelah ditransformasi diperoleh nilai $R$ Square sebesar 0,372 dengan tingkat 37,2 persen. Jadi, pengaruh Likuiditas, Ukuran Perusahaan, Profitabilitas dan Leverage terhadap Nilai Perusahaan sebesar 37,2 dan sisanya 62,8 di pengaruh oleh variabel lain yang tidak diteliti dapa penelitian ini.

Tabel 10

Hasil Uji F

\begin{tabular}{|c|c|c|c|c|c|c|}
\hline \multicolumn{2}{|c|}{ Model } & Sum of Squares & $\mathrm{df}$ & Mean Square & $\mathrm{F}$ & Sig. \\
\hline \multirow{3}{*}{1} & Regression & 14,666 & 4 & 3,667 & 8,897 &, $000^{\mathrm{b}}$ \\
\hline & Residual & 24,727 & 60 & ,412 & & \\
\hline & Total & 39,393 & 64 & & & \\
\hline
\end{tabular}

Sumber : olahan data

Tabel 10 diatas setelah ditransformasi dapat dilihat bahwa nilai $F_{\text {hitung }}$ sebesar 8,897 dan nilai $F_{\text {tabel }}$ adalah sebesar $1\left(\mathrm{df}_{1}\right) \mathrm{k}=3$, dan derajat bebas $2\left(\mathrm{df}_{2}\right)=\mathrm{n}-\mathrm{k}-1=65-4-1=60$, dimana $\mathrm{n}=$ jumlah sampel, $\mathrm{k}=$ jumlah variabel bebas, nilai $\mathrm{f}_{\text {tabel }}$ pada taraf kepercayaan signifikansi 0,05 adalah 2,53 dengan demikian $\mathrm{f}_{\text {hitung }}=8,897$ maka kesimpulannya adalah $F_{\text {hitung }}>F_{\text {tabel }}=8,897>2,53$ dengan nilai signifikansi $0,000<0,05$. Jadi, secara simultan Likuiditas, Ukuran Perusahaan, Profitabilitas dan Leverage berpengaruh dan signifikan terhadap Nilai Perusahaan pada sub sektor Wholesale yang terdaftar di Bursa Efek Indonesia pada periode 2014-2018.

Tabel 11

Hasil Uji t

\begin{tabular}{|c|c|c|c|c|c|c|}
\hline \multicolumn{2}{|c|}{ Model } & \multicolumn{2}{|c|}{ Unstandardized Coefficients } & $\begin{array}{c}\text { Standardized Coefficients } \\
\text { Beta } \\
\end{array}$ & $\mathrm{t}$ & Sig. \\
\hline \multirow{5}{*}{1} & (Constant) & B 1,378 & $\begin{array}{l}\text { Std. Error } \\
1,199\end{array}$ & & 1,150 & ,255 \\
\hline & Ln_Likuiditas & ,691 & 165 &, 595 & 4,197 &, 000 \\
\hline & Ln_Ukuran Perusahaan & ,207 &, 342 &, 064 &, 605 &, 548 \\
\hline & Ln_Profitabilitas & ,788 &, 153 & ,649 & 5,170 &, 000 \\
\hline & Ln_Leverage &, 592 &, 163 &, 582 & 3,629 &, 001 \\
\hline
\end{tabular}

Sumber : olahan data

Dengan pengujian 2 sisi (signifikansi $=0,025$ ) hasil diperoleh untuk t tabel sebesar 2,00030 (60) masingmasing variabel independen secara parsial terhadap variabel dependen dapat dianalisis sebagai berikut :

1. Likuiditas mempunyai nilai t-hitung 4,791 dengan tingkat Signifikan 0,000. Sedangkan nilai t-tabel adalah sebesar 2,00030 dengan signifikan 0,05. Sehingga kesimpulannya adalah t-hitung > t-tabel yaitu 4,197 > 2,00030 dan nilai sig < 0,05 maka artinya variabel Likuiditas secara parsial berpengaruh dan signifikan terhadap terhadap nilai perusahaan pada perusahaan sub sektor Wholesale yang terdaftar di Bursa Efek Indonesia pada periode 2014-2018.

2. Ukuran Perusahaan mempunyai nilai t-hitung 0,605 dengan tingkat Signifikan 0,548. Sedangkan nilai t-tabel adalah sebesar 2,00030 dengan signifikan 0,05. Sehingga kesimpulannyaadalah t-hitung >t-tabel yaitu 0,605< 2,00030 dan nilai sig < 0,05. Maka artinya variabel ukuran perusahaan secara parsial tidak berpengaruh dan tidak signifikan terhadap terhadap nilai perusahaan pada perusahaan sub sektor Wholesale yang terdaftar di Bursa Efek Indonesia pada periode 2014-2018.

3. Profitabilitas mempunyai nilai t-hitung 5,170 dengan tingkat Signifikan 0,000. Sedangkan nilai t-tabel adalah sebesar 2,00030 dengan signifikan 0,05. Sehingga kesimpulannya adalah t-hitung $>$ t-tabel yaitu 5,170>2,00030 dan nilai sig $<0,05$ maka artinya variabel Profitabilitas secara parsial berpengaruh dan signifikan terhadap 
Andreas Siagian dan Desstevinalia Br Surbakti, Pengaruh Likuiditas, Ukuran Perusahaan, Profitabilitas dan Laverage Terhadap Nilai Perusahaan pada Perusahaan Sub Sektor Wholesale yang Terdaftar di Bursa Efek Indonesia Periode 2014-2018

terhadap nilai perusahaan padaperusahaan sub sektor Wholesale yang terdaftar di Bursa Efek Indonesia pada periode 2014-2018.

4. Leverage mempunyai nilai t-hitung 3,629 dengan tingkat Signifikan 0,001. Sedangkan nilai t-tabel adalah sebesar 2,00030 dengan signifikan 0,05. Sehingga kesimpulannya adalah t-hitung $>\mathrm{t}$-tabel yaitu 3,629>2,00030 dan nilai sig $<0,05$ maka artinya variabel Leverage secara parsial berpengaruh dan signifikan terhadap terhadap nilai perusahaan pada perusahaan sub sektor Wholesale yang terdaftar di Bursa Efek Indonesia pada periode 20142018.

\section{Pengaruh Likuiditas Terhadap Nilai Perusahaan}

Berdasarkan hasil uji (t) diperoleh bahwa t-hitung > t-tabel dan nilai sig lebih kecil dari 0,05 maka Likuiditas secara parsial berpengaruh dan signifikan terhadap Nilai Perusahaan pada sub sektor Wholesale yang terdaftar di Bursa Efek Indonesia pada periode 2014-2018. Hasil ini sejalan dengan penelitian (Susilaningrum,2016) yang mengatakan bahwa variabel kinerja keuangan yang diproksikan dengan rasio likuiditas berpengaruh positif signifikan terhadap nilai perusahaan. Nilai perusahaan yang diperoleh atas kegiatan operasional selama beberapa tahun ditentukan oleh kepercayaan masyarakat terhadap perusahaan. Meningkatnya nilai suatu perusahaan merupakan sebuah prestasi, karena hal ini berarti kesejahteraan perusahaan beserta pemilik juga semakin meningkat. Sedangkan rasio likuiditas yang menggambarkan kinerja keuangan perusahaan dari segi kewajiban dapat mempengaruhi penilaian masyarakat khususnya investor dalam rangka memberikan kepercayaan kepada perusahaan untuk menanamkan modal.

\section{Pengaruh Ukuran Perusahaan Terhadap Nilai Perusahaan}

Berdasarkan hasil uji (t) diperoleh bahwa t-hitung < t-tabel dan nilai sig lebih besar dari 0,05 maka Ukuran Perusahaan secara parsial tidak berpengaruh dan tidak signifikan terhadap Nilai Perusahaan pada sub sektor Wholesale yang terdaftar di Bursa Efek Indonesia pada periode 2014-2018. Hasil ini sejalan dengan penelitian (Manoppo, 2016) mengatakan bahwa ukuran perusahaan tidak berpengaruh signifikan terhadap nilai perusahaan Ukuran perusahaan umumnya berpengaruh pada penilaian investor dalam membuat keputusan investasi. Ukuran perusahaan diukur dengan besarnya total asset yang dimiliki karena nilai total asset umumnya sangat besar dibandingkan variabel keuangan lainnya. Ukuran perusahaan bukan merupakan pertimbangan bagi para investor dalam berinvestasi. Ukuran perusahaan yang besar belum bisa menjamin nilai perusahaannya tinggi, karena perusahaaan besar mungkin belum berani melakukan investasi baru terkait dengan ekspansi, sebelum kewajibankewajibannya (hutang) sudah terlunasi. Hal ini juga menunjukkan besar kecilnya perusahaan tidak akan berpengaruh dengan besar kecilnya perusahaan.

\section{Pengaruh Profitabilitas Terhadap Nilai Perusahaan}

Berdasarkan hasil uji $(\mathrm{t})$ diperoleh bahwa t-hitung > t-tabel dan nilai sig lebih kecil dari 0,05 maka Profitabilitas secara parsial berpengaruh dan signifikan terhadap Nilai Perusahaan pada sub sektor Wholesale yang terdaftar di Bursa Efek Indonesia pada periode 2014-2018. Hasil ini sejalan dengan penelitian (Nandita, 2018) yang mengatakan profitablitas berpengaruh positif dan signifikan terhadap nilai perusahaan. Dapat disimpulkan bahwa hipotesis pertama diterima, semakin tinggi profit perusahaan maka akan memberikan sinyal kepada investor bahwa perusahaan memiliki kondisi dan prospek yang bagus dimasa mendatang. Sehingga akan menarik minat investor untuk menanamkan modalnya. Tingginya permintaan harga saham akan meningkatkan harga saham. Harga saham yang tnggi berarti berpengaruh terhadap nilai perusahaan.

\section{Pengaruh Leverage Terhadap Nilai Perusahaan}

Berdasarkan hasil uji (t) diperoleh bahwa t-hitung > t-tabel dan nilai sig lebih kecil dari 0,05 maka leverage secara parsial berpengaruh dan signifikan terhadap Nilai Perusahaan pada sub sektor Wholesale yang terdaftar di Bursa Efek Indonesia pada periode 2014-2018. Hasil ini sejalan dengan penelitian (Herawati, 2017) yang mengatakan leverage berpengaruh positif signifikan terhadap nilai perusahaan penggunaan leveragemampu meningkatkan nilai perusahaan karena dalam perhitungan pajak, bunga yang dikenakan akibat penggunaan hutang dikurangkan dahulu, sehingga mengakibatkan perusahaan memperoleh keringanan pajak.

\section{Simpulan}

Berdasarkan hasil penelitian dan pembahasan tentang pengaruh Likuiditas, Ukuran Perusahaan, Profitabilitas dan Leverage terhadap Nilai Perusahaan kesimpuan yang dapat ditarik yaitu :

1. Likuiditas secara parsial berpengaruh dan signifikan terhadap terhadap Nilai Perusahaan pada perusahaan sub sektor Wholesale yang terdaftar di Bursa Efek Indonesia pada periode 2014-2018. 
Andreas Siagian dan Desstevinalia Br Surbakti, Pengaruh Likuiditas, Ukuran Perusahaan, Profitabilitas dan Laverage Terhadap Nilai Perusahaan pada Perusahaan Sub Sektor Wholesale yang Terdaftar di Bursa Efek Indonesia Periode 2014-2018

2. Ukuran Perusahaan secara parsial tidak berpengaruh dan tidak signifikan terhadap terhadap Nilai Perusahaan pada perusahaan sub sektor Wholesale yang terdaftar di Bursa Efek Indonesia pada periode 2014-2018.

3. Profitabilitas secara parsial berpengaruh dan signifikan terhadap terhadap Nilai Perusahaan padaperusahaan sub sektor Wholesale yang terdaftar di BursaEfek Indonesia pada periode 2014-2018.

4. Leverage secara parsial berpengaruh dan signifikan terhadap terhadap Nilai Perusahaan pada perusahaan sub sektor Wholesale yang terdaftar di Bursa Efek Indonesia pada periode 2014-2018.

5. secara simultan Likuiditas, Ukuran Perusahaan, Profitabilitas dan Leverage berpengaruh dan signifikan terhadap Nilai Perusahaan pada sub sektor Wholesale yang terdaftar di Bursa Efek Indonesia pada periode 2014-2018.

\section{Daftar Pustaka}

Agus Sartono. (2012). Manajemen Keuangan Teori dan Aplikasi. Edisi4. BPFE. Yogyakarta.

Arindita, G., \& Sampurno, R. D. (2015). Analisis Pengaruh Struktur Modal, Profitabilitas, Kebijakan Dividen, dan Size terhadap Nilai Perusahaan (Studi Kasus pada perusahaan Wholesale dan Retail yang terdaftar di BEI tahun 2008-2012), Doctoral dissertation, Fakultas Ekonomika dan Bisnis.

Bambang, Riyanto. (2012). Dasar-dasar Pembelanjaan, Edisi 4, Yogyakarta: BPFE

Brigham, Euqene F., and Houston, Joel F. (2011). Dasar-Dasar Manajemen Keuangan, Edisi Kesebelas Jilid Dua. Terjemahan Oleh Ali Akbar Yulianto. Jakarta:Salemba Empat.

Fahmi, Irham. (2014). Analisa Kinerja Keuangan. Bandung : Alfabeta

Gozali, I. (2018). Aplikasi Analisis Multivariate dengan Program IBM SPSS 25. Edisi 9. Semarang: Undip

Herawati, L. N. A. (2017). Pengaruh Ukuran Perusahaan, Leverage, Pertumbuhan Penjualan Dan Profitabilitas Terhadap Nilai Perusahaan Pada Perusahaan Yang Terdaftar Dalam Indeks LQ45, Doctoral dissertation, STIE Perbanas Surabaya.

Husnan, Suad. (2014). Manajemen Keuangan Teori dan Penerapan (Keputusan Jangka Panjang). Edisi Keempat. Yogyakarta: BPFE.

I Made Sudana. (2011). Manajemen Keuangan PerusahaanTeori dan Praktik. Jakarta: Erlangga

Jayaningrat, I. G. A. A., Wahyuni, M. A., \& Edy Sujana, S. E. (2017). Pengaruh Leverage, Profitabilitas, Likuiditas, Kebijakan Deviden, Kepemilikan Manajerial, Dan Kepemilikan Institusional Terhadap Nilai Perusahaan Pada Perusahaan Properti Dan Real Estate Di Bursa Efek Indonesia Tahun 2013-2015. JIMAT (Jurnal Ilmiah Mahasiswa Akuntansi) Undiksha, 7(1).

Kasmir. 2016. Analisis Laporan Keuangan. Jakarta: Raja Grafindo Persada.

Lumoly, S., Murni, S., \& Untu, V. N. (2018). Pengaruh Likuiditas, Ukuran Perusahaan dan Profitabilitas terhadap Nilai Perusahaan (Studi pada Perusahaan Logam dan Sejenisnya yang Terdaftar di Bursa Efek Indonesia). Jurnal EMBA: Jurnal Riset Ekonomi, Manajemen, Bisnis dan Akuntansi, 6(3).

Manoppo, H., \& Arie, F. V. (2016). Pengaruh Struktur Modal, Ukuran Perusahaan Dan Profitabilitas Terhadap Nilai Perusahaan Otomotif Yang Terdaftar Di Bursa Efek Indonesia Periode 2011-2014. Jurnal EMBA: Jurnal Riset Ekonomi, Manajemen, Bisnis dan Akuntansi, 4(2).

Mardiyati, U., Ahmad, G. N., \& Putri, R. (2012). Pengaruh kebijakan dividen, kebijakan hutang dan profitabilitas terhadap nilai perusahaan manufaktur yang terdaftar di Bursa Efek Indonesia (BEI) periode 2005-2010. JRMSI-Jurnal Riset Manajemen Sains Indonesia, 3(1), 1-17.

Nandita, A., \& Kusumawati, R. (2018). Pengaruh Profitabilitas, Leverage, Siize Dan Kebijakan Dividen Terhadap Nilai Perusahaan. Cam Journal: Change Agent For Management Journal, 2(2), 188-199.

Nur Aisyah, R. (2015). Pengaruh Likuiditas dan Struktur Modal Terhadap Nilai Perusahaan (Studi pada perusahaan pertambangan logam dan mineral yang terdaftar di Bursa Efek Indonesia Periode 2009-2013), Doctoral dissertation, Universitas Komputer Indonesia.

Prasetyorini, F., \& Fitri, B. (2013). Pengaruh ukuran perusahaan, leverage, price earning ratio dan profitabilitas terhadap nilai perusahaan. Jurnal Ilmu Manajemen (JIM), 1(1).

Rudangga, I. G. N. G., \& Sudiarta, G. M. (2016). Pengaruh ukuran perusahaan, leverage, dan profitabilitas terhadap nilai perusahaan. E-Jurnal Manajemen Universitas Udayana, 5(7).

Sari, M. R. P. A., \& Handayani, N. (2016). Pengaruh Profitabilitas, Ukuran Perusahaan dan Leverage, terhadap Nilai Perusahaan Transportasi. Jurnal Ilmu dan Riset Akuntansi (JIRA), 5(9).

Sartono, Agus. 2010. Manajemen Keuangan Teori dan Aplikasi. Edisi 4. Yogyakarta : BPFE.

Solikahan, E. Z., Ratnawati, K., \& Djawahir, A. H. (2013). Pengaruh Leverage dan Investasi terhadap Nilai Perusahaan (Studi pada Perusahaan Makanan dan Minuman di Bursa Efek Indonesia). Jurnal Aplikasi Manajemen, 11(3), 427-433.

Sugiyono. (2016). Metode Penelitian Kuantitatif Kualitataif dan Kombinasi (Mixed Methods). Bandung: Alfabeta. 
Andreas Siagian dan Desstevinalia Br Surbakti, Pengaruh Likuiditas, Ukuran Perusahaan, Profitabilitas dan Laverage Terhadap Nilai Perusahaan pada Perusahaan Sub Sektor Wholesale yang Terdaftar di Bursa Efek Indonesia Periode 2014-2018

Susilaningrum, C. (2016). Pengaruh Return on Assets, Rasio Likuiditas, Dan Rasio Solvabilitas Terhadap Nilai Perusahaan Dengan Pengungkapan Corporate Social Responsibility (Csr) Sebagai Variabel Moderasi. Jurnal Profita: Kajian Ilmu Akuntansi, 4(8).

Suwardika, I. N. A., \& Mustanda, I. K. (2017). Pengaruh leverage, ukuran perusahaan, pertumbuhan perusahaan, dan profitabilitas terhadap nilai perusahaan pada perusahaan properti. E-Jurnal Manajemen Universitas Udayana, 6(3).

Ramadhani, R. Akhmadi dan Kuswantoro.(2018). Pengaruh Leverage dan Profitabilitas Terhadap Nilai Perusahaan Dengan Kebijakan Dividen Sebagai Variabel Intervening. Jurnal Riset Bisnis dan Manajemen Tirtayasa (JRBMT), 2(1), 21-42.

Yanti, I. G. A. D. N., \& Darmayanti, N. P. A. (2019). Pengaruh Profitabilitas, Ukuran Perusahaan, Struktur Modal, dan Likuiditas Terhadap Nilai Perusahaan Makanan dan Minuman. E-Jurnal Manajemen, 8(4), 2297-2324 